\title{
Counterfactual and non-counterfactual conditional constructions in Kuikuro (Upper Xingu Carib)
}

\section{Construções condicionais contrafactuais e não contrafactuais em Kuikuro (Karib alto-xinguano)}

\author{
Bruna Franchetto (D) \\ Universidade Federal do Rio de Janeiro. Rio de Janeiro, Rio de Janeiro, Brasil
}

\begin{abstract}
Kuikuro is one of the varieties of the Upper Xingu Carib Language, of the Southern Xinguan Branch of the Carib family, which is spoken by approximately 600 people, in the region known as the Upper Xingu, at the southern edge of the Brazilian Amazon. This article focuses on counterfactual and non-counterfactual conditional constructions in Kuikuro. After an introduction containing the relevant information on methodology, theoretical background and the main questions that arise from the Kuikuro data, the article is further organized into two sections. The first one offers a brief introduction to the Kuikuro people and a sketch of the Kuikuro morphosyntactic typology and the relevant grammatical facts. The second section describes counterfactual and non-counterfactual conditional constructions. The results of this preliminary study show that Kuikuro speakers have multiple morphosyntactic resources available to realize utterances expressing conceptual and pragmatic domains of possibility, whether these are asserted, assumed, or denied.
\end{abstract}

Keywords: Kuikuro. Upper Xingu. Carib. Counterfactual conditionals. Non-counterfactual conditionals.

Resumo: Kuikuro é uma das variedades da língua Karib alto-xinguana, um dos dois ramos meridionais da família Karib, e é falado por 600 pessoas na região conhecida como alto Xingu, periferia meridional da Amazônia. Este artigo foca nas construções condicionais contrafactuais e não contrafactuais em Kuikuro. Após uma introdução contendo informações relevantes sobre metodologia, referências teóricas e as principais questões que emergem dos fatos Kuikuro, o artigo é organizado em duas seções. A primeira oferece uma breve introdução aos Kuikuro e um esboço da tipologia morfossintática de sua língua, assim como dos fatos gramaticais relevantes. A segunda seção descreve as construções contrafactuais e não contrafactuais. Os resultados deste estudo preliminar mostram os recursos morfossintáticos disponíveis aos falantes kuikuro para realizar enunciados no domínio conceitual e pragmático da possibilidade, seja ela asserida ou assumida, seja ela negada.

Palavras-chave: Kuikuro. Alto Xingu. Karib. Condicionais contrafactuais. Condicionais não contrafactuais.

Franchetto, B. (2021). Counterfactual and non-counterfactual conditional constructions in Kuikuro (Upper Xingu Carib). Boletim do Museu Paraense Emílio Goeldi. Ciências Humanas, 16(3), e20200107. doi: 10.1590/2178-2547-BGOELDI-2020-0107

Autora para correspondência: Bruna Franchetto. Universidade Federal do Rio de Janeiro. Rua Professor Ortiz Monteiro, 276, ap. 405 C. Rio de Janeiro, RJ, Brasil. CEP 22245-100 (bfranchetto@yahoo.com.br).

Recebido em 09/09/2020

Aprovado em 05/07/2021

Responsabilidade editorial: Adam Singerman 


\section{INTRODUCTION}

This article focuses on non-counterfactual and counterfactual conditional constructions in Kuikuro, a variety of the Upper Xingu Carib Language (LKAX), one of the two southern branches of the Carib family (Meira \& Franchetto, 2005). It is a pilot descriptive study of these constructions in a specific language, whose results, at the moment, offer new data for further developments and comparison with other Carib languages and beyond, as well as for theoretical approaches and interpretations.

According to Ferreira and Müller (2019, pp. 1066-1067), based on Von Fintel (2001, p. 1515):

Conditional sentences talk about a possible scenario that may or may not be the case and describes what else is the case in that scenario. . . . the if-clause sets up the possible scenario; the then-clause asserts what is the case in that scenario.

The term antecedent refers to the if-clause and the term consequent refers to the then-clause.

In other words, in non-counterfactual conditionals (henceforward non-CF), ". . . the truth of the antecedent is an open issue", while in counterfactual conditionals (henceforward CF) 'the antecedent is false' (Ferreira \& Müller, 2019 , p. 1067), as exemplified by the Kuikuro sentences (1) and (2). ${ }^{1}$

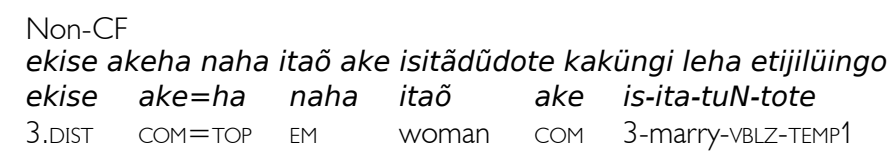

(2) inhalü isinümingo uma ekubetsü! isitoteha uãke tügekuili leha tisipolü

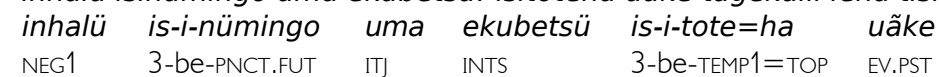

tügekuili leha tis-i-po-lü

happy COMPL 1.3-be-HYP-PNCT

'He will not come, too bad! If he came, we would be happy.'

Examples (1) and (2) exemplify the most common types of construction in Kuikuro for non-CFs and CFs, respectively. If the same kind of temporal subordinate clause caracterizes the antecedent, a different verbal inflection distinguishes the consequent: Punctual aspect followed by Future in non-CF; Hypothetical mood followed by Punctual aspect in CF. The consequence, or implicature, of (1) is that it is not possible to know whether he married that woman or not, while the consequence, or implicature, of (2) is, obviously, that we are not happy. Kuikuro would be one of the few languages that have a morpheme restricted to counterfactuality (Ferreira \& Müller, 2019, p. 1053): the Hypothetical

In the examples, the two parts of the conditional constructions have been separated, for their interlinearization, in the second and fourth lines.

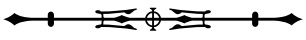


mood. Then, the difference in meaning is associated with a difference in verbal morphology, as latridou (2000, p. 232) predicts, but the Kuikuro case compels us to look outside verbal morphology as well.

Considering counterfactual constructions more specifically, I quote latridou (2000, p. 231): "Counterfactuality refers to gramatical construction that express or make reference to situations that are contrary to the fact". The antecedent $p$ and the consequent $q$ do not hold at present or at a particular time in the past. Conditionals are not the only kind of CF constructions: wishes also convey counterfactuality if the proposition expressed by the subordinate clause is false. ${ }^{2}$

The Kuikuro verb is only inflected for mood and aspect, not for tense. Tense morphemes are particles outside the verbal word. This makes necessary some dialogue with the recent debate on Tense in counterfactual conditional constructions. For a theoretical approach and a basic definition of Tense, I quote Ferreira and Müller (2019, p. 1960):

According to Klein (1994), time is a notional category. Eventualities are described by human languages as occurring before, after or concomitantly to the Utterance Time. These notions are referred to as past, present and future. Languages may mark them on their verbs throught morphological means., a linguistic category distinct from Time (present, past, future), a notional category tha languages may express on verbs throught morphological means. Tense, on the other hand, is a linguistic category. It is anchored to the Utterance Time. Klein (1994) defines tense as a relation between two time intervals: the moment the sentence is uttered and the moment or interval referred to by the topic of the conversation (Klein, 1994). The first one is called Utterance Time (henceforth UttT) and the latter is called Topic Time (henceforth TopT) [added emphasis].

Schematically, the present tense refers to the coincidence between Topic Time and Utterance Time (TopTUttT), the past tense refers to Topic Time anterior to Utterance Time (Top $T<U t t T)$, and future tense refers to Topic Time posterior to Utterance Time (TopT > UttT).

Within the limits of this article and of my competence, I restrict my theoretical references to latridou (2000) and Ferreira and Müller (2019), avoiding semantic formalizations and trying to extract from these authors some ideas that can provide a more insightful look at the Kuikuro data.

The first question concerns whether Kuikuro can fit into the typology that would define whether a language is of the past/non-past type, or of the future/non-future type or even of the past/present/future type. We face a challenge: Is Kuikuro a future-non future language as is the case with Karitiana, a Tupian Amerindian language, analyzed by Ferreira and Müller, where non-past verbal inflection covers both the semantic present and the semantic past? Or does it not fit the existing typologies, considering the most recent ones (Ferreira \& Müller, 2019)?

A second question now arises, which is also difficult to answer from the Kuikuro data, coming from the following concluding statements by latridou (2000) regarding CFs: if CFs must contain past tense morphology in both the antecedent and the consequent, is the past tense morphology a required component of CF morphology? I leave the reader with the two references used in this article so that she can have a clear view of the debate around the nature of past tense in CFs, which latridou (2000) describes for in various languages around the world and Ferreira and Müller (2019) in Karitiana.

Possible answers to the above questions, at the moment, will be summarized at the end of this article.

Regarding the methodology used in this study, the source of the analyzed subcorpus - sixty CFs, forty non-CFs - comes from the existing digital Kuikuro corpus which results from 40 years of documentation work conducted by

2 Due to space limitations, in this article I will not deal with 'wish'-conditionals. There is no verb 'want' in Kuikuro and in other known Carib languages. Wishes are expressed by adverbial clauses headed by a postposition and subordinated to the verbal copula.

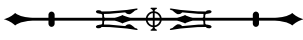


the author and which contains narratives, among other performed discourse genres, and elicited data contextualized whenever possible (Matthewson, 2004; Sanchez-Mendes, 2014). Five narratives belonging to three different sub-genres (mythical, historical, personal) were examined and the subcorpus of conditionals was checked by the author in fieldwork realized in July 2019 and remotely in 2020, with Kuikuro consultants.

Following this introduction, the rest of the article is organized into two main sections. The first one includes the necessary background information not only on the Kuikuro people and their language, but especially on the grammatical phenomena that are relevant for the understanding of conditional constructions, both non-CFs and CFs: Tense Aspect Mood (TAM) inflection, temporal subordination or framing, epistemics and evidentials. As stated earlier, the Kuikuro verbs are inflected for mood and aspect, but not for tense, with the exception of a future/modal that follows the aspectual inflection. Time/tense interpretation results contextually from the interaction between aspects, adverbs, epistemics and deictics. In addition, Kuikuro has a specialized verbal mood to express possibility, feasible or unrealized, with mandatory presence in counterfactual conditional constructions. Finally, the temporal subordination characterizes the antecedent of many conditional constructions, and some epistemics, as mentioned, contribute decisively to the interpretation of temporal reference and counterfactuality. The second section of the article deals, in details, with the organized description of the four constructions and the three constructions that the Kuikuro speakers have at their disposal for non-CFs and CFs respectively. These complex constructions are analyzed in their constituent parts, for which I reserve the classic terms of 'antecedent' and 'consequent', describing different patterns of the asymmetric relationship between them. The antecedent's dependent character is evident in a continuum between, on the one hand, adverbial dependent clauses encoded as a type of time framing and containing nominalized (deverbalized) forms of the verb, and, on the other hand, in a clearly biclausal pattern: the index of its dependence is expressed by epistemics and adverbs of temporal framing. We will also face the problem of the indistinction between non-CFs and CFs in two types of construction and I will point how to get out of this apparent uncomfortable overlapping.

The examples in this article are presented with the following structure: the first and second lines of the examples are presented in orthographic transcription ${ }^{3}$; second and third lines show the morphological segmentation of each word and the interlinear glossing, respectively; the fourth line contains a balanced translation between fidelity to the original and some degree of freedom for a better understanding by the reader.

\section{THE KUIKURO PEOPLE AND THEIR LANGUAGE}

Kuikuro, one of the two main dialects of the Upper Xingu Carib Language (LKAX), is spoken by approximately 600 people. They live in six villages in the region known as 'Upper Xingu', where the headwaters of the Xingu river, one of the largest southern tributaries of the Amazon river, are located, at the edge of Southern Amazonia, Brazil. Kuikuro people inhabit the southeast of the Xingu Indigenous Land (TIX), between the Culuene and the Buriti rivers, where they have lived since at least the first half of the $18^{\text {th }}$ century. The term 'Kuikuro' has been frozen as a permanent ethnonym since the first written ethnographical record by Karl von den Steinen at the end of the 19 ${ }^{\text {th }}$ century (Steinen, 1894), and it derives from the toponym of the place where, in the middle of the 18th century, the first Kuikuro village ('Kuhi ikugu', 'Needle Fish Creek') was built as an autonomous group of the multilingual and multiethnic Upper Xingu regional system. Kuikuro should be considered

3 Kuikuro (alphabetic) writing was developed by indigenous teachers, in collaboration with the author, in the 1990s. The correspondences between 'letters' or groups of letters (including digraphs and trigraphs) and symbols from the International Phonetic Alphabet (IPA), when different, are as follows: ü (ł), j (j), g (uvular flap), ng ( $\mathrm{\eta}), \mathrm{nh}(\mathrm{n}), \mathrm{nkg}\left({ }^{\mathrm{n}} \mathrm{g}\right)$; N represents a subspecified fluctuating nasal.

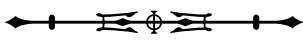


a still vital, albeit vulnerable, language/variety. Upper Xingu Carib dialects are distinguished mainly by different prosodic structures (Silva \& Franchetto, 2011). The speakers of these varieties - Kuikuro, Kalapalo, Nahukua and Matipu - are part of the Upper Xingu Carib sub-system.

In this section, I lay down the basic facts about Kuikuro grammar, with particular attention to those that are relevant for the understanding of the data and its analysis.

Kuikuro is a highly agglutinative and complement-head order language (Maia et al., 2019, pp. 85-91). Argumental complements precede verbs, nouns and postpositions; subordinate clauses normally precede main clauses. The basic word order is subject intransitive-verb (SV) and object transitive-verb subject (OVS); any head, be it a verb, a noun or a postposition, constitutes a prosodic unit with its internal argument (Silva \& Franchetto, 2011). It is an ergative-absolutive language (all intransitive verbs are unaccusative); the agent or external cause of a transitive verb is marked by the postposition heke (Franchetto, 2010). There is no overt agreement on the verb and a unique set of person markers is prefixed as internal (absolutive) argument to verbs, nouns and postpositions. Bare nominals are underdetermined for number and definiteness. ${ }^{4}$

(3a) kangamuke inilũdagü kangamuke iniluN-tagü

child cry-DUR

'A child is crying.', 'The child is crying.', 'Children are crying.', 'The children are crying.'

(3b) isinilũdagü

is-iniluN-tagü

3-cry-DUR

'She/He is crying.'

(4a) kangamuke engetagü uakungagü heke kangamuke enge-tagü u-akunga-gü heke child eat-DUR 1-shadow-POSS ERG 'My shadow is scaring (a/the) child/children.'

(4b) u-enge-tagü u-akunga-gü heke u-enge-tagü u-akunga-gü heke 1-eat-DUR 1-shadow/soul-POSS ERG 'My shadow is scaring me.'

A complex allomorphy, determined by five morphological classes, characterizes many inflectional nominal and verbal suffixes (Franchetto, 1986; Santos, 2007, 2008). Kuikuro shows also a rich phonological conditioned allomorphy of bound morphemes (Franchetto, 1995).

Tables 1 and 2 below schematize the structures of the nominal and verbal words in Kuikuro, with the positions of prefixes and suffixes, before and after the root, which I consider an uncategorized lexical morpheme. Morphemes in brackets are optional.

4 On Kuikuro morphosyntax, see, among other publications: Franchetto (2006, 2010, 2015); Santos (2007, 2008); Franchetto and Santos (2010, 2014, 2017, 2018); Franchetto and Thomas (2016); Maia et al. (2019).

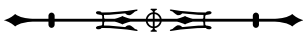


Table 1. The structure of the Kuikuro nominal word. Legends: Abs/Pers = absolutive (internal argument) pronominal prefixes; Ncat = low nominal categorizer; NMLZ = nominalizer; POSS = possessive; FUT = future; NTM = nominal tense marker; COP = non-verbal copula.

\begin{tabular}{|l|l|l|l|l|l|l|l|l|}
\hline (Abs/Pers) & Root & Ncat & (Aspect) & (NMLZ) & (POSS) & (Number) & (FUT/NTM) & (COP) \\
\hline
\end{tabular}

Table 2. The structure of the Kuikuro verbal word. Legends: Abs/Pers = absolutive (internal argument) pronominal prefixes; DTR = detransitivizer; Vcat = low verbal categorizer; VBLZ = verbalizer; TR = transitivizer; FUT = future; NTM = nominal tense marker; $\mathrm{COP}=$ non-verbal copula.

\begin{tabular}{|l|l|l|l|l|l|l|l|l|l|l|}
\hline (Abs/Pers) & (DTR) & Root & Vcat & VBLZ & (TR) & Mood & Aspect & (Number) & (FUT) & (COP) \\
\hline
\end{tabular}

In the following subsections I will present in some detail the morphosyntactic characteristics that are relevant for the description of the phenomena under scrutiny. In the first section, we will see that Kuikuro verbs are inflected for mood and aspect, not for tense. Time/tense is inferred contextually from the interaction between aspects, adverbs, epistemics and deictics. However, there is a future verbal inflection. In addition, Kuikuro has a specialized verbal mood to express possibility, feasible or unrealized, with mandatory presence in counterfactual conditional constructions. Finally, it is necessary to briefly present the temporal subordination (or framing), which characterizes the antecedent of many conditional constructions, and the epistemics involved in conditional constructions.

\section{KUIKURO TAM INFLECTION}

\section{Aspect (tense)}

The Kuikuro language does not have tense verbal inflection per se, but only aspectual verbal inflection. Despite being the dominant feature of verbal inflection in Kuikuro, aspects do not seem to play a significant role in conditional constructions. CFs in Kuikuro are not limited to a particular aspect marking.

The Punctual Aspect (PNCT) - with its allomorphs -lü, -jü, -nügü - is a kind of default aspect. It expresses an eventuality conceived as instantaneous, without any inherent duration in time, 'almost a thing' as the Kuikuro say. Punctual aspect is interpreted as referring to a non-present eventuality, anterior to Utterance Time (UttT), as shown in $(5 a, 5 b)$ and by the agrammaticality of (5c).

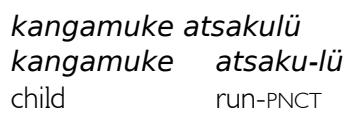

(5b) konige kangamuke atsakulü

konige kangamuke atsaku-lü

yesterday child run-PNCT

'Yesterday the child ran.'

(5c) *kangamuke atsakulü ãde ekugu kangamuke atsaku-lü ãde ekugu

child run-PNCT now INTS

'The child runs right now.'

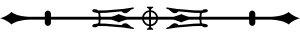


The Durative aspect (DUR) - with its allomorphs -tagü, -tsagü, -gagü - can be considered as an imperfective and expresses an eventuality conceived in their inherent duration in time. It is underdetermined for past and present tense, as exemplified by $(6 a, 6 b)$, and it locates the reference time within the Topic Time (the time of the eventuality described by the speaker).

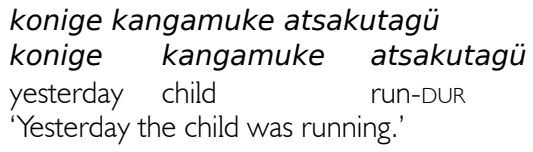

(6b) kangamuke atsakutagü ãde ekugu

$\begin{array}{llll}\text { kangamuke atsaku-tagü ãde } & \text { ekugu } \\ \text { child } & \text { run-DUR } & \text { now } & \text { INTS }\end{array}$

'The child is running right now.'

The Perfect aspect (PRF) - with its alomorphs -pügü, -tühügü, -tsühügü - refers to an eventuality completed before the TopicTime (TopT). One of my Kuikuro consultants explained the meaning of the Perfect aspect with a thought-provoking metaphor: "I think it would be the spot, the trace, the trail of something". ${ }^{5}$ That said, he suggested that the best translation would be through a past participle, as in (7, 8, 9), examples taken from narratives. The speaker is the story-teller in (7) and (9), while in (8) it is one of the characters whose speech is quoted by the story-teller. Note that the completive or terminative aspectual particle leha goes almost always with the verb inflected by Perfect aspect. ${ }^{6}$

(7) imükuhegipügü leha ungu heke leha

$\begin{array}{llll}\text { imü-kuhegi-pügü leha ungu heke leha } \\ \text { face-drip-PRF } & \text { COMPL blood ERG COMPL }\end{array}$

'The blood had dripped over the face.'

(8) 'k-ingajomo-ko heke ngapale ihi-pügü leha ige-i'

k-ingajomo-ko heke ngapale ihi-pügü ige-i

1.2-sisters-PL ERG maybe stir-PRF DPROX-COP

'Maybe this is the stirred by our sisters.' (maybe this is what/where our sisters have stirred it)

(9) inha apugati i hotakipügü leha
inha apugati $i$ hotaki-pügü leha
hole to.inside wood sharp-PRF COMPL
'At the bottom of the hole (there were) sharp sticks.' (whose tips had been sharpened)

In Kuikuro, the suffix -ingo (FUT), always after the verbal Punctual aspect, could be considered as the only genuine expression of tense, but it expresses more than just a future tense, as far as it has also deontic modal values of possibility and commitment.

In Portuguese: "Acho que seria o lugar, a marca, o rastro".

6 The aspectual completive particle leha, and the clitic =ha are ubiquitous. leha closes main as well secondary predications. The clitic =ha is still under investigation, but it seems to mark the single topic of the utterance as well as its possible multiple topics. For an analysis of the left periphery in Kuikuro, see Franchetto and Santos (2010), Franchetto (2015), and Maia et al. (2019, pp. 120-129).

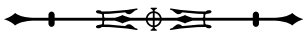


(10)

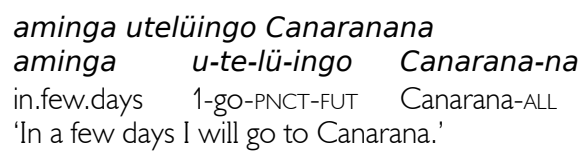

(11) inhalü gehale i agugijüingo hõhõ uheke

inhalü gehale $i$ agugi-jü-ingo hõhõ u-heke

NEG1 again wood Cut-PNCT-FUT EMPH 1-ERG

'I can't again, I have to cut firewood.'

Furthermore, just the use of the suffix -ingo, in a biclausal construction of a paratactic type, is enough to express a non-CF, as in (12).

(12) Kogetsi kongoho ngingilüingo, uge apa inhümingo gele üngá

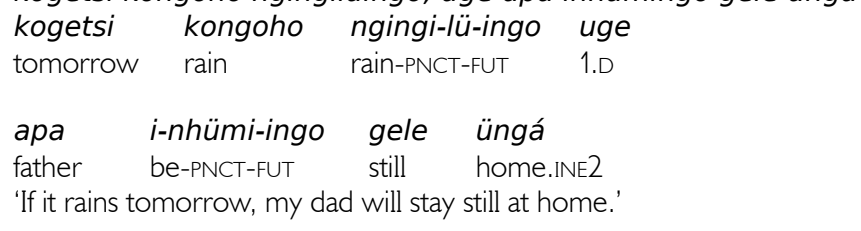

Tense either is inferred from aspects in a pragmatic context or it is expressed through adverbs - like ãde, 'now, today'; konige, 'yesterday; kogetsi, 'tomorrow; uãke, distant past - and even through epistemic particles.

The uãke particle deserves a comment since it is relevant for the analysis of Kuikuro conditional constructions and a clear case of the interpenetration of temporal and epistemic values. It is a particle in second position, that is, after the first constituent of the sentence, and it can be repeated after each constituent when the speech assumes a particularly emphatic style, characteristic of the speech made publicly by a chief. Uãke is both a distant past and an epistemic that I have called 'authorative voice' (Franchetto, 2007, p. 191). Basso (2012, pp. 376-77), defines the same particle in Kalapalo, a Kuikuro co-variety, as a "strong assertive form. . . . A speaker bears witness to evidence from the distant past. . . . (it) does not mark first-hand evidence, but strong and justifiable conviction". The example below is an excerpt from a 'historical' narrative told by an old Kuikuro chief to the author in 1981:

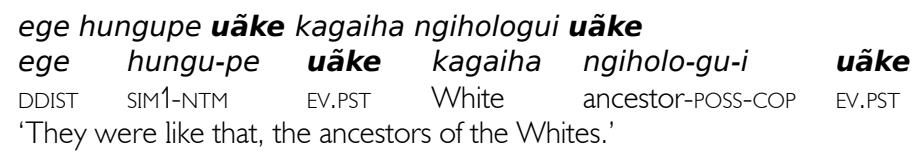

(13b) ngiholo eale uãke tü-te-ga-tinhü-pe kagaiha ngiholo-gu ngiholo e-ale uãke tü-te-ga-tinhü-pe kagaiha ngiholo-gu ancestor kill-SIMLT EV.PST ANA-gO-DUR-NANMLZ-NTM White ancestor-POSS 'The ancestors of the Whites were those who were going killing (our) ancestors.'

Another frequent means for express tense is through the complex formed by a deictic of proximity or distance (to the speaker) suffixed with the non-verbal copula $-i$, at the right edge of the left periphery of the sentence. Sentences, when uttered in natural contexts, are, more than often, a kind of biclausal constructions, in which only one constituent 
is highlighted as focus. The deictic plus non-verbal copula is responsible for the finite (tense) interpretation of the main verb. Compare (14a) and (14b).

(14a) hikutaha eseii uingãdzu ngengetagüi

$\begin{array}{llll}\text { hikutaha } & \text { ese-i } & \text { u-ingãdzu } & \text { ng-enge-tagü-i } \\ \text { turtle } & \text { 3.PROX-COP } & 1 \text {-sister } & \text { O-eat-DUR-COP }\end{array}$

'It is the/a turtle that my sister is eating.'

(14b) hikutaha ekisei uingãdzu ngengetagüi

$\begin{array}{llll}\text { hikutaha ekise-i } \quad \text {-ingãdzu } & \text { ng-enge-tagü-i } \\ \text { turtle } & \text { 3.DIST-COP } 1 \text {-sister } & \text { O-eat-DUR-COP } \\ \text { 'It was the/a turtle that my sister was eating.' }\end{array}$

(14b) cannot be used for a future interpretation; in this case the verb must be inflected by the future suffix -ingo, and the deitic can be either proximal or distal:

hikutaha esei/ekisei uingãdzu ngengelüingoi kogetsi
$\begin{array}{llll}\text { hikutaha ese-i/ekise-i u-ingãdzu } & \text { ng-enge-lü-ingo-i } & \text { kogetsi } \\ \text { turtle } & \text { 3.PROX-COP/3.DIST-COP 1-sister } & \text { O-eat-PNCT-FUT-COP } & \text { tomorrow } \\ \text { 'It will be the/a turtle that my sister will eat.' } & & \end{array}$

The semantics of the nominal suffix -pe (NTM) has the value of a terminative aspect (Franchetto \& Thomas, 2016) and it can also contribute to the interpretation of a past eventuality. In (15), an example taken from a mythical narrative, -pe occurs in the logophoric üngele leading to the understanding of the eventuality expressed by the nominalized verb as necessarily prior to TopT.?

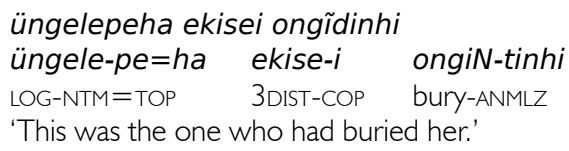

\section{The hypothetical (HYP) mood}

The structure of the verbal word in Table 2 shows that mood is expressed by bound morphemes as suffixes immediatly after the stem. There is no Declarative mood or it is not phonologically realized. Among the other moods - Imperative, Hortative, Habitual - I deal here briefly with what I call the Hypothetical mood (HYP), since its presence is mandatory in the consequent or both in the antecedent and consequent of CFs.

The grammatical morpheme -ho- is the phonological exponent of the HYP mood, with its phonologically conditioned allomorphs -po- and -mbo-. It follows the verbal stem, precedes the aspectual inflection and it expresses possibility, whether it is asserted or assumed (factual), or denied (counterfactual).

The HYP mood marks sentences interpretable and translatable as expressing a possibility, as in the examples from (16) to (21).

7 Looking at the translation of the Gospels into Kuikuro, carried out by Kuikuro consultants of evangelical missionaries, I was impressed by the abundant use of the nominal suffix -pe in an attempt to convey the past tense verbal inflection in Portuguese, the source-language, which results in a proliferation of atypical constructions at the limit of agrammaticality.

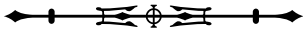


(16) ẽbuta iliholüha ege-i u-heke

$\begin{array}{llll}\text { ẽbuta ili-ho-lü=ha } & \text { ege-i } & \text { u-heke } \\ \text { medicine drink-HYP-PNCT=TOP } & \text { DDIST-COP } & \text { 1-ERG } \\ \text { 'Maybe I drink the medicine.' } & & \end{array}$

(17) kogetsi ũbege kanga engeholü uheke

$\begin{array}{lllll}\text { kogetsi ũbege } & \text { kanga enge-ho-lü } & \text { u-heke } \\ \text { tomorrow } & \text { FR } & \text { fish } & \text { eat-HYP-PNCT } & 1 \text {-ERG }\end{array}$

'Maybe I will eat fish tomorrow.'

(18) angí uẽbolü

angí u-ẽN-po-lü

INT 1-enter-HYP-PNCT

'Can I come in?'

(19) ekege apüngũbotagü leha

ekege apünguN-ho-tagü leha

jaguar die-HYP-DUR COMPL

'Maybe the jaguar is dying.'

(20) kogetsi uehugu ihipütehopügü leha uheke

$\begin{array}{llll}\text { kogetsi u-ehu-gu ihipüte-ho-pügü leha } & \text { u-heke } \\ \text { tomorrow 1-boat-POSS buy-HYP-PRF } & \text { COMPL } & \text { 1-ERG } \\ \text { 'Tomorrow I will have already bought my boat.' } & & \end{array}$

(21) uinha akatsange isipolü

$\begin{array}{lll}\text { u-inha akatsange is-i-po-lü } & \\ \text { 1-DAT1 really } & \text { 3.come-HYP-PNCT }\end{array}$

'Maybe he will come to me.'

The sentence initial particle engapa, with its epistemic hypothetical value, cannot co-occurs with the HYP mood, as in (22).

\begin{tabular}{|c|c|c|c|c|c|}
\hline engapa & t-ihí & leha & hüle & a-nügü & leha \\
\hline EM.if & ANA-ran.away.PTCP & COMPL & CNTR & stay-PNCT & COMPL \\
\hline nügü & i-heke & & & & \\
\hline say.PNCT & 3-ERG & & & & \\
\hline
\end{tabular}

In interrogative constructions, the Hypothetical mood is often accompanied by the indefinite interrogative particle angí, as in the example (18), and the epistemic clitic kaha, which conveys ". . . a feeling of strong probability, the almost certainty of the speaker who seeks a confirmative answer from the interlocutor" (Franchetto \& Santos, 2010, p. 97). In other words, the speaker communicates that she/he knows that the addressee knows the answer. I will return to the concomitance of epistemic particles and the Hypothetical mood when I present in more detail the conditionals constructions.

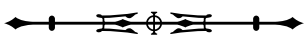


(23)

angíkaha uteholü aakeni
$\begin{array}{lll}\text { angí=kaha } & \text { u-te-ho-lü } & \text { a-ake-ni } \\ \text { INT=EM } & \text { 1-go-HYP-PNCT } & \text { 2-COM-PL } \\ \text { 'Can I go with you?' }\end{array}$

The counterfactual possibility is always marked by the HYP mood, as in the examples below.

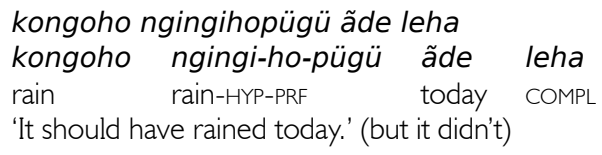

(26) latsi ekugu ulamakiholü

latsi ekugu u-lamaki-ho-lü

almost INTS 1-fell-HYP-PNCT

'I almost fell.' (but I didn't)

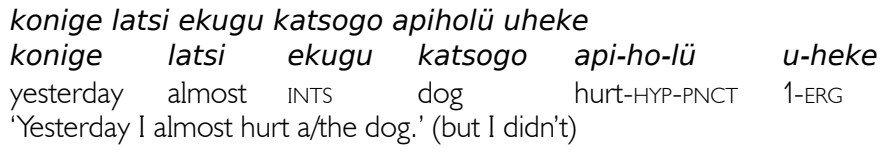

If we compare the examples from (16) to (21) with the examples from (24) to (27), a question arises: what would distinguish the interpretation of 'possibility' from the interpretation of 'counterfactuality'? The difference, which I tried to capture in the translations and based on speaker comments, is undoubtedly subtle. The better answer I can offer at the moment follows Iatridou (2000, p. 246): the Hypothetical (HYP) mood seems to separate the Topic Time (TopT) from the Utterance Time (UttT), setting topic worlds (= topic time) that exclude the world of the speaker and her certainty about eventualities only, of course, hypothesized. In this sense, it seems to me that the HYP mood has an epistemic value that encompasses possibility and counterfactuality, whose differentiation is contextually inferred, and sometimes pointed out by other elements in the utterance, such as the frustrative particle ũbege in (17).

\section{TEMPORAL SUBORDINATION}

Two types of adverbial clauses introduce the reference time of the matrix clause and they express the temporal subordination or the dependent temporal framing in the antecedent of many conditional constructions.

The first type of adverbial temporal clause is headed by the postposition -tote (TEMP1, with its allomorphs -tsote, -gote and -sote), suffixed to the uninflected verbal stem.

(28) isünkgügoteha ihüsoho ünkgüngalü tühitsetiale tinahulunale gehale is-ünkgü-gote=ha i-hüsoho ünkgü-nga-lü tü-hitse-ti-ale

3-sleep-TEMP1=TOP 3-mother.in.law sleep-HAB-PNCT REFL-fart-VBLZ-SIMLT

t-inahulun-ale gehale

REFL-Snore-SIMLT also

'When he was sleeping, his mother-in-law always slept farting and also snoring.'

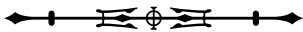


The postposition atai (glossed as TEMP2) takes as its argument a nominal or a pronominal form and heads the second type of adverbial temporal clause.

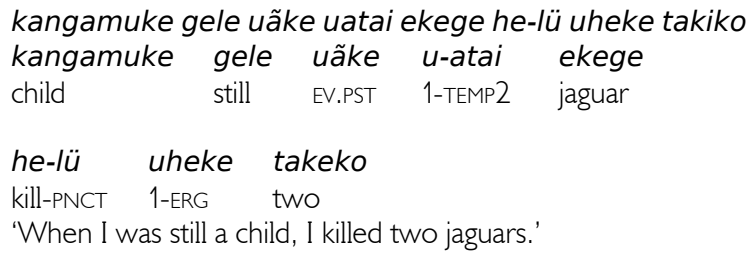

\section{EPISTEMICS}

Among the many kuikuro epistemics, most of them second-position cliticizable particles, I deal here only with those involved in conditional constructions. In section 'Aspect Tense', the morpheme uãke was interpreted as associated to a temporal (distant past) value and to the epistemic value of an 'authorative voice' by which the speaker gives the utterance a strong degree of certainty. Naha and tsüha ${ }^{8}$ are two other epistemic particles relevant for the discussion of the analysed corpus.

Naha is a second position particle with epistemic value and it is present in most non-CFs and CF constructions: "Using naha the speaker communicates the wish that the hearer will accept and understand the explanation and that she/he is confident that the hearer will agree with the statement" (Franchetto \& Santos, 2010, pp. 97-98).

Naha can be cliticized to initial angí, a particle also used in yes-no questions. The Kuikuro explain that angí expresses the speaker's desire to know what the addressee thinks about the communicated question. In non-interrogative sentences, the same angí is followed by the epistemic naha, introducing the antecedent of a conditional construction, where verbs in both antecedent and consequent are inflected with Hypothetical Mood. ${ }^{9}$ The following example is reproduced from Franchetto and Santos (2010, pp. 97-98). Heeding suggestion Haegeman (2004, p. 161), I could suggest that naha introduces a kind of peripheral adverbial clause, which:

... express a premise which is entertained by the speaker and which serves as privileged context for the processing of the main clause. . . . the relevant adverbial clause provides discourse background that serves as restrictors for processing, against such backgrounds the matrix clause yields particular contextual implicatures.

(30) Context: the speaker explains why it is not acceptable to count beyond the number 20, using the toes on another person's foot.

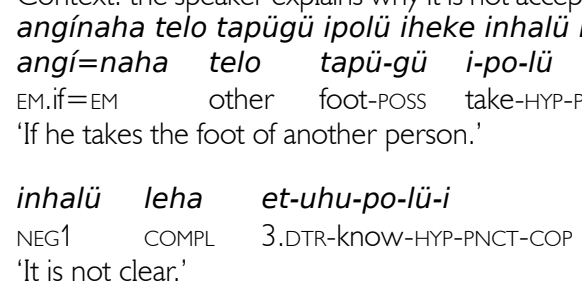

8 Naha and tsüha are glossed, respectively, as EM and CR2; EM means just epistemic, a specific gloss has not yet been defined.

9 The interrogative particle angí is related to angi, an indefinit deictic, but they are distinguished by the pitch stress: on the last syllable in the former (with raising intonation), on the penultimate syllable in the latter (general and predictable pattern). Angi is used in answer to questions of the kind 'where is X?' indicating $X$ in the space near and visible to both speaker and listener (Franchetto \& Santos, 2010, p. 110, note 7).

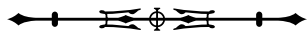


Table 3. Types of construction for non-CFs and CFs in Kuikuro.

\begin{tabular}{|l|l|l|}
\hline Non-CF/CF antecedent & Non-CF consequent & CF consequent \\
\hline Temp. sub. clause & Future tense & Hypothetical mood \\
\hline $\begin{array}{l}\text { Epistemic naha } \\
\text { Future tense }\end{array}$ & Future tense & \\
\hline $\begin{array}{l}\text { Epistemic naha } \\
\text { Hypothetical mood }\end{array}$ & Hypothetical mood & Hypothetical mood \\
\hline $\begin{array}{l}\text { Epistemic enaha } \\
\text { Hypothetical mood }\end{array}$ & Hypothetical mood & Hypothetical mood \\
\hline
\end{tabular}

If we look at the types of construction (i), (ii) and (iii) and Table 3, it is easy to establish a first generalization: nonCFs and CFs are distinguished by the use of Future tense/modal exclusively in non-CFs, while HYP mood marks CFs. See the contrast between non-CFs and CFs in the data from (32) to (33), as well as the use of the past tense/epistemic uãke and the epistemic tsüha.

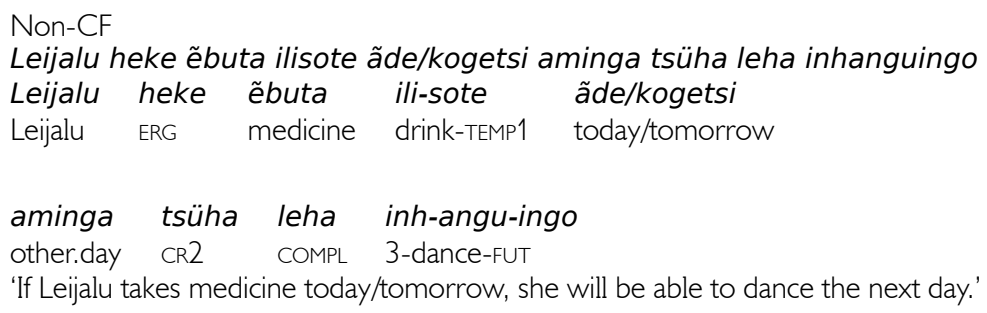

Note that in (32), where the antecedent is a temporal framing subordinate clause, the consequent contains the Future morpheme-ingo in verb inflection and, in addition, the tsüha epistemic particle which adds an indirect certainty.

(33a) Leijalu heke naha ẽbuta ilisote konige, ãde leha inhangumbolü

$\begin{array}{llllll}\text { Leijalu heke } & \text { naha } & \text { ẽbuta ili-sote } & \text { konige } \\ \text { Leijalu } & \text { ERG } & \text { EM } & \text { medicine } & \text { drink-TEMP1 } & \text { yesterday }\end{array}$

ãde leha inh-anguN-po-lü

today COMPL 3-dance-HYP-PNCT

'If Leijalu had taken medicine yesterday, today she would dance.'

(I know she didn't, as you also know)

(33b) Leijalu heke naha ẽbuta ilisote konige ãde tsüha leha inhangumbolü

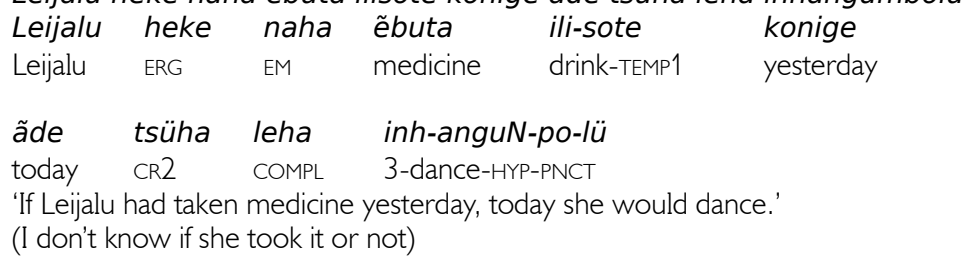

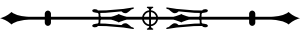


(33c) Leijalu heke ẽbuta ilisote naha uãke hekite tsüha leha ipopügü

$\begin{array}{llllll}\begin{array}{l}\text { Leijalu } \\ \text { Leijalu }\end{array} & \text { ERG } & \begin{array}{l}\text { ẽbuta } \\ \text { medicine }\end{array} & \begin{array}{l}\text { ili-sote drink-TEMP1 } \\ \text { EM }\end{array} & \text { EV.PST } \\ \text { hekite } & \text { tsüha } & \text { leha } & \text { i-po-pügü } & & \\ \text { good } & \text { CR2 } & \text { COMPL } & \text { 3-HYP-PRF } & & \end{array}$

'If Leijalu had taken medicine time ago, she would have been fine.'

(I think that she didn't)

The above non-CFs and (past) CFs constructions have the same subordinate clause with an uninflected verb as antecedent, but they contrast in the verbal inflectional morphology in their consequent: Future for non-CF, HYP mood for CF. Moreover, the distinction between a recent past and a more distant past, in (33b) and (33c), is given by adverbial particles (konige versus uãke). Again, the epistemic tsüha, absent in (33a), modularizes the degree of certainty communicated by the speaker in (33b) and (33c): I know that vs I don't know if or I think that. The examples (34) and (35) below confirm the basic contrastive characteristics of Kuikuro non-CFs and CFs.

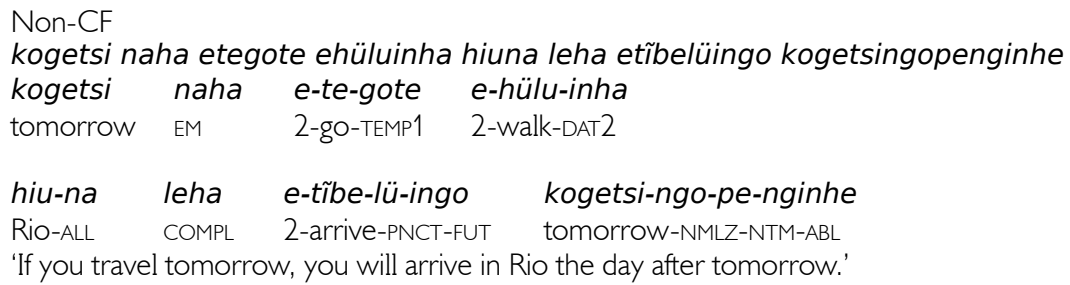

(35) aminga naha tegiküi atai konige leha tetĩbe ipopügü

aminga naha t-egiküí atai konige leha t-etĩbé i-po-pügü
other.day EM ANA-travel.PTCP TEMP2 yesterday COMPL ANA-arrive.PTCP be-HYP-PRF 'If he had traveled the day before yesterday, he would have arrived yesterday.'

A problem seems to arises with types (iv) and (V), which apparently do not distinguish between non-CFs and CFs. In subsections 'Non-CFs and CFs with the epistemic particle naha in the antecedent, and the verb inflected for HYP Mood in both the antecedent and the consequent' and 'Non-CFs and CFs with the antecedent introduced by the initial epistemic particle enaha and HYP Mood in both antecedent and consequent', I will point out some clues to solve this problem.

The following subsections contain more examples of each type of construction.

\section{NON-CF WITH AN ADVERBIAL TEMPORAL SUBORDINATE CLAUSE AS ANTECEDENT, AND THE VERB INFLECTED FOR FUTURE TENSE/MODAL IN THE CONSEQUENT}

The examples from (36) to (38) show the antecedent expressed by the temporal framing adverbial headed by the postposition -tote and its allomorphs (-tsote, -gote, -sote) conditioned by the morphological classes, suffixed to the non-inflected verb and glossed as TEMP1. The verb in the consequent is in all cases inflected by the Punctual aspect followed by fut modal/tense -ingo. 
(36) kuigiku ilisote uheke hekite ekuleha uünkgülüingo ${ }^{11}$

$\begin{array}{lllll}\text { kuigiku ili-sote } & \text { u-heke hekite } & \text { eku=leha } & \text { u-ünkgü-lü-ingo } \\ \text { kuigiku drink-TEMP1 } & \text { 1-ERG } & \text { well } & \text { INTS=COMPL } & 1 \text {-sleep-PNCT-FUT }\end{array}$

'When/if I take kuigiku today, I will sleep well.'

atanga hetegoteha eheke telope hanümingo leha uheke
atanga he-te-gote=ha e-heke telo-pe ha-nümingo leha u-heke
flute $\quad$ break-TEMP1=TOP 2-ERG other-NTM make-PNCT.FUT COMPL 1-ERG

'When/if you break the flute, I'll make another one for you.'

anetü ügünũdoteha hüatiko ingenümingo tuhugu leha kupehe
$\begin{array}{llllll}\text { anetü ügünuN-tote=ha hüati-ko inge-nümingo tuhugu } & \text { leha } & \text { kupehe } \\ \text { chief } \quad \text { be.sick-TEMP1=TOP shaman-PL call-PNCT.FUT } & \text { PL } & \text { COMPL } & \text { 1.2.ERG }\end{array}$

'If the chief gets sick, we'll call all the shamans.'

The example (39) shows another temporal adverbial clause as antecedent, now headed by the postposition atai (glossed as TEMP2), whose argument is an explicitly nominalized verb.

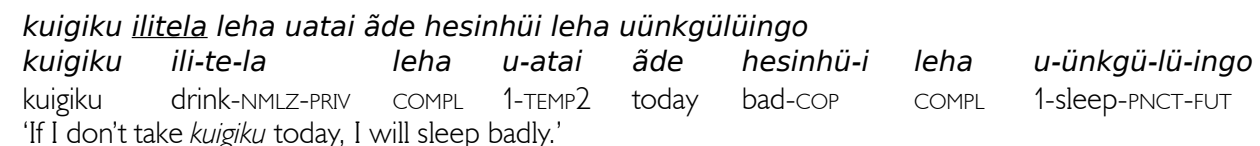

'If I don't take kuigiku today, I will sleep badly.'

Note the lack of the HYP mood in the consequent if all the above non-CF constructions.

\section{NON-CF ANTECEDENT WITH THE EPISTEMIC PARTICLE naha, AND THE VERB INFLECTED WITH FUTURE TENSE/MODAL IN BOTH ANTECEDENT AND CONSEQUENT}

In this type of non-CFs, exemplified from (40) to (42), both verbs in antecedent and consequent are inflected by Future modal/tense and the naha epistemic particle clearly marks the antecedent; note that naha occurs always in second position, that is, after the first constituent, identified by brackets, in the left periphery of the sentence or, in other words, in CP (complementizer phrase).

(40) [ahukugu helüingo] naha eheke ukotuingo leha

$\begin{array}{lllll}\text { ahukugu he-lü-ingo naha e-heke u-ko-tuN-ingo leha } \\ \text { pot break-PNCT-FUT EM } & \text { 2-ERG } & 1 \text {-rage-VBLZ-FUT COMPL } \\ \text { 'If you break the pot, I will be angry.' (I'm afraid you will break the pot) } & \end{array}$

(41) [tegipanetila] naha einhümingo inhalü tsüma ilainha atahehijü uhunümingo eheke

$\begin{array}{lllll}\begin{array}{l}\text { t-eg-ipane-ti-la } \\ \text { ANA-2.DTR-accustom-PTCP-PRIV }\end{array} & \text { EM } & \text { 2-be-FUT } & \text { NEG1 } & \text { EM } \\ & & & \\ \text { ilainha } & \text { at-ahehi-jü } & \text { uhu-nümingo } & \text { e-heke } \\ \text { D.DIR } & \text { 2.DTR-trace-PNCT } & \text { know-FUT.NEG } & \text { 2-ERG } \\ \text { 'If you don't study, you won't write.' (I'm not so sure that you will dedicate yourself to study) }\end{array}$

${ }_{11}^{11}$ Kuigiku is a kind of porridge made with wild manioc. 


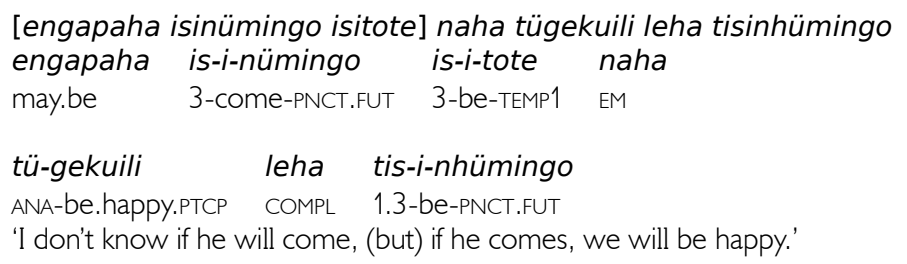

Epistemic particles convey the speaker's communicative intentions, including values of degrees of certainty or uncertainty. From what we saw in the section on epistemics and from the spontaneous comments of the speaker reproduced in parentheses after the translation of the examples (40) and (41), naha seems to be associated with a temporal anteriority, not exactly with a past value, and, above all, it does seem to convey a lesser degree of certainty regarding the possibility of realization of the eventuality hypothesized by the antecedent, as well as an intimate alignment with the interlocutor ('as you know').

\section{CFS WITH TEMPORAL SUBORDINATE CLAUSE AS ANTECEDENT AND THE VERB INFLECTED WITH HYP MOOD IN THE CONSEQUENT}

The verb of the adverbial dependent temporal clause, headed by atai, can be inflected with Punctual aspect, as in (43) and (44), or, much more often, is overtly nominalized, as in (45) to (48). All these complex sentences describe a past counterfactual possibility, a TopT anterior to the UttT. HYP mood inflection marks only the verb of the consequent, followed by Punctual or Perfect.

\begin{tabular}{|c|c|c|c|c|}
\hline $\begin{array}{l}\text { konige } k \\
\text { konige } \\
\text { yesterday }\end{array}$ & $\begin{array}{l}\text { Koho ngin } \\
\text { kongoho } \\
\text { rain }\end{array}$ & $\begin{array}{c}\text { ilü atai uge } \\
\text { ngingi-lü } \\
\text { rain-PNCT }\end{array}$ & $\begin{array}{ll}\text { le apa ipol } \\
\ddot{u} & \text { atai } \\
& \text { TEMP2 }\end{array}$ & $\begin{array}{l}\text { le üngá } \\
\text { uge } \\
\text { 1.D }\end{array}$ \\
\hline $\begin{array}{l}\text { apa } \\
\text { father }\end{array}$ & $\begin{array}{l}\text { i-po-lü } \\
\text { be-HYP-PNCT }\end{array}$ & $\begin{array}{l}\text { gele } \\
\text { still }\end{array}$ & $\begin{array}{l}\text { üngá } \\
\text { home.INE2 }\end{array}$ & \\
\hline
\end{tabular}

(44) (From the narrative ĩbe opogipügü, 'the appearing (origin) of the pequi tree') $)^{12}$

$\begin{array}{lll}\text { nügü ataiha egei iheke } & & \\ \text { nügü } \quad \text { atai=ha } \quad \text { ege-i } & \text { i-heke } \\ \text { (speak).PNCT TEMP1=TOP DDIST-COP } & \text { 3-ERG } \\ \text { 'If (pequi) had spoken to him (Taũgi).' } & \end{array}$

ihü pekugiti ihisü ipogagü

ihü pekugiti i-hi-sü i-po-gagü

body full 3-fruit-Poss be-HYP-DUR

'In the full body/trunk its fruits would have remained.'
İbe hisü ipogagü
ĩbe hi-sü i-po-gagü
pequi fruit-Poss be-HYP-DUR
'The pequi fruits would have remained.'

\footnotetext{
12 At the end of the narrative entitled ĩbe opogipügü - the appearing (origin) of the pequi tree - Taũgi, the ancestral demiurge and creative trickster, provokes the transformation of the primordial pequi, born from the buried body of the Hyper-Alligator, into the pequi that still exists today, with its fruits reduced only to the tips of the branches. The kuõ and kugĩda trees answer to the demiurge's call: 'In their full branches and in their trunks their fruits will be'. Pequi answered the third call: 'At the ends of your branches your fruits will be'.
}




ĩkungu pekugiti ihisü ipogagü

ĩkungu pekugiti i-hi-sü i-po-gagü

arm full 3-fruit-POss be-HYP-DUR

'In its full arms / branches would have remained.'

(45) uge amape apüngu leha ege isuã tapünginhüpei atai ige isuã ülegote umukugu ingiholü iheke ${ }^{13}$

$\begin{array}{llllll}\text { uge } & \text { ama-pe } & \text { apünguN } & \text { leha } & \text { ege } & \text { isuã } \\ \text { 1.D } & \text { mother-NTM } & \text { die.PNCT } & \text { COMPL } & \text { DDIST } & \text { dry.season }\end{array}$

$\begin{array}{llll}\text { t-apüngi-nhü-pe-i } & \text { atai } & \text { ige } & \text { isuã üle-gote } \\ \text { ANA-die.PTCP-NANMLZ-NTM-COP } & \text { TEMP2 } & \text { DPROX } & \text { dry.season LOG-TEMP1 }\end{array}$

u-muku-gu ingi-ho-lü i-heke

1-son-POSS See-HYP-PNCT 3-ERG

'My mother died last year; if she had died this year, then she would have met my son.'

(46) tüihetinhüi uãke uatai ege isuã ãde ekuguha kaküngi kuiginhu ipopügü ungipi

$\begin{array}{llllll}\text { tü-ihe-ti-nhü-i } & \text { uãke } & \text { u-atai } & \text { ege } & \text { isuã } & \text { ãde } \\ \text { ANA-plant-PTCP-NANMLZ-COP } & \text { EV.PST } & 1-T E M P 2 & \text { DDIST } & \text { dry.season now }\end{array}$

ekugu=ha kaküngi kuiginhu i-po-pügü u-ngipi

INTS=TOP many manioc.flour be-HYP-PRF 1-have

'If I had planted manioc last year, now I would have a lot of manioc flour.'

(47) tankginhüi uatai alemanhate uipolü leha alemaĩ uitaginhũbolü leha alemaũ

$\begin{array}{lllll}t \text {-ankgi-nhü-i } & u \text {-atai } & \text { Alemanha-te } & u \text {-i-po-lü } & \text { leha } \\ \text { ANA-nascer-NANMLZ-COP } & 1 \text {-TEMP2 } & \text { Germany-INE1 } & 1 \text {-be-HYP-PNCT } & \text { COMPL }\end{array}$

$\begin{array}{llll}\text { alemã-i } & \text { u-itaginhuN-po-lü } & \text { leha alemaũ } \\ \text { German-COP } & \text { 1-speak-VBLZ-HYP-PNCT } & \text { COMPL } & \text { German }\end{array}$

'If it had been born in Germany, I would be German and I would speak German.'

(48) konige hungu kohotsi kuigiku ilinhi uatai hekite uünkgüholü

$\begin{array}{llllll}\text { konige } & \text { hungu } & \text { kohotsi } & \text { kuigiku } & \text { ili-nhi } & \text { u-atai } \\ \text { yesterday } & \text { SIM1 } & \text { evening } & \text { kuigiku } & \text { drink-ANMLZ } & 1 \text {-TEMP2 }\end{array}$

hekite u-ünkgü-ho-lü

well 1-sleep-HYP-PNCT

'If yesterday afternoon I had kuigiku, I would have slept well.'

\section{CFS WITH TEMPORAL SUBORDINATE CLAUSE AND THE EPISTEMIC naha AS ANTECEDENT AND THE VERB INFLECTED WITH HYP MOOD IN THE CONSEQUENT}

The CFs from (49) to (52) present the following structure: (i) antecedent with the sequence NP, the adverbial subordinators atai or -tote-, the epistemic naha and an overtly nominalized verb; (ii) consequent with the verb inflected with HYP mood. It should be noted that the aspect that follows the Hypothetical mood seems to determine a different temporal interpretation: non-past with punctual aspect, as in (49), and past with Perfect aspect, as in (50), (51) and (52).

13 The suffixes - $n h u ̈$, in examples from (45) to (47), and - $n h i$, in (48), are different nominalizers, sensitive to the argument structure of the verb, and glossed, respectively, NANMLZ (non-agent nominalizer) for the absolutive arguments $\mathrm{s}$ and $\mathrm{O}$, and ANMLZ (agent nominalizer) for the external argument A of transitive verbs (Franchetto, 2010; Franchetto \& Santos, 2014). 
(49) (Context: $A$ claims to have seen Bruna on the way to the bathing place; $B$ replies)

B. tuãka naha tütenhüi atai inhalüha ege ima eteholüi

$$
\begin{array}{llll}
\begin{array}{l}
\text { tuã-ka } \\
\text { water-AQU.INE }
\end{array} & \text { EM } & \begin{array}{l}
\text { tü-te-nhü-i } \\
\text { ANA-gO-NANMLZ-COP }
\end{array} & \text { atai } \\
\text { TEMP2 } & \\
\text { inhalü=ha ege ima e-te-ho-lü-i } & \\
\text { NEG1=TOP DDIST path } & \text { 3-gO-HYP-PNCT-COP } \\
\text { 'If she was going to bathe, she wouldn't be walking that way.' }
\end{array}
$$

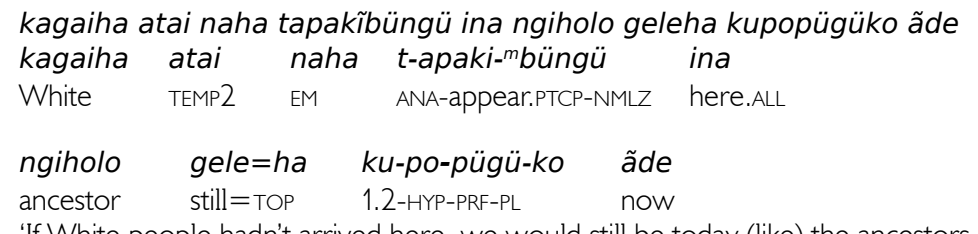

(51) Ahinhuka atai naha kagahina tũdinhi kinhani kagaiha leha ãde kupopügüko

$\begin{array}{llllll}\text { Ahinhuka atai } & \text { naha kagahina tuN-tinhi } & k \text {-inha-ni } \\ \text { Ahinhuka } & \text { TEMP2 } & \text { EM } & \text { carbine } & \text { give-ANMLZ } & 1.2-D A T 1-P L\end{array}$

kagaiha leha ãde ku-po-pügü-ko

White COMPL now 1.2-HYP-PRF-PL

'If Ahinhuka had given carbine to kuge ${ }^{14}$, today we would be (like) the White people.'

(52) tühepãdĩbüngü naha katamini kagutu ikihopügü leha konige giti elü hata

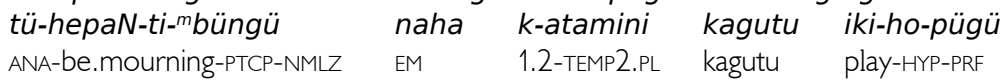

leha konige giti e-lü hata

COMPL yersterday sun kill-PNCT TEMP3

'If we weren't in mourning, the kagutu flutes would have played yesterday in the eclipse of the sun.'

The next subsections ('Non-CFs and CFs with the epistemic particle naha in the antecedent, and the verb inflected for HYP Mood in both the antecedent and the consequent' and 'Non-CFs and CFs with the antecedent introduced by the initial epistemic particle enaha and HYP Mood in both antecedent and consequent') presents some challenging data, as they seem to show an apparent non-distinction between non-CFs and CFs.

\section{NON-CFS AND CFS WITH THE EPISTEMIC PARTICLE naha IN THE ANTECEDENT, AND THE VERB INFLECTED FOR HYP MOOD IN BOTH THE ANTECEDENT AND THE CONSEQUENT}

\section{Non-CF}

(53) is the only example in my corpus of what seems to be a non-CF, but, surprisingly, with the verb inflected by HYP mood both in the antecedent and in the consequent. I do not have a satisfactory interpretation, but I decided to include

\footnotetext{
14 The word kuge refers to the peoples of the Upper Xingu, who share the same socio-cultural system and, above all, the same morality or civility. kuge can be analyzed as derived from kukuge, dual inclusive pronoun deictic.
} 
it for the readers' appreciation, suggesting, at the moment, that we are dealing with a hypothesis of an extremely distant or unlikely possible world.

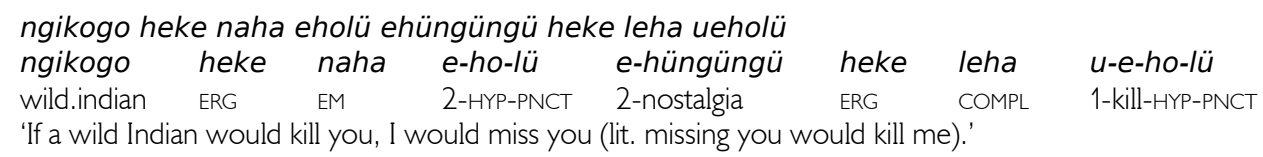

$\mathrm{CF}$

On the other hand, the CF construction with the epistemic naha in the antecedent and with the fully inflected verbs in both the antecedent and the consequent containing the HYP mood is very productive.

(54) umugu heke naha Kuikuro akisü uhupolü aake leha itaginhũbolü

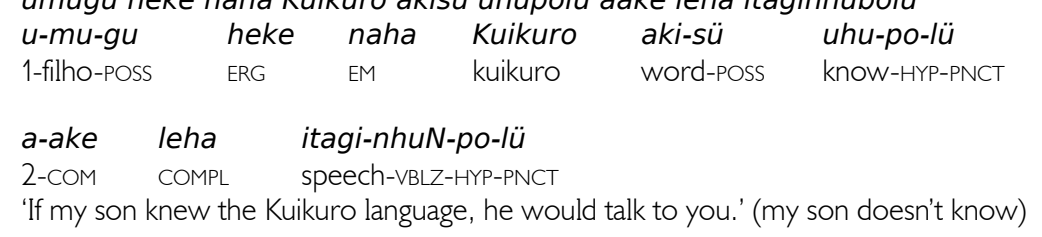

(55) Bruna heke naha ahĩtsa ikenipolü inegetumbolü leha üngá tinhügü heke ünga

$\begin{array}{lllll}\begin{array}{l}\text { Bruna heke naha ahĩtsa } \\ \text { Bruna }\end{array} & \text { ERG EM } & \begin{array}{l}\text { ikeni-po-lü } \\ \text { believe-HYP-PNCT }\end{array} & \begin{array}{l}\text { inege-tuN-po-lü } \\ \text { fear-VBLZ-HYP-PNCT }\end{array} \\ \text { leha } & \text { t-i-nhügü } & \text { heke üngá } \\ \text { COMPL ANA-be-PNCT PRS house.INE2 } & \end{array}$

(56) kapehe naha uipolü egena leha hügeku tüiholü uheke kapehe

\begin{tabular}{|c|c|c|c|c|c|c|}
\hline $\begin{array}{l}\text { kapehe } \\
\text { high }\end{array}$ & $\begin{array}{l}\text { naha } \\
\text { EM }\end{array}$ & $u-i$ & 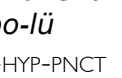 & $\begin{array}{l}\text { ege-na } \\
\text { DDIST-ALL }\end{array}$ & $\begin{array}{l}\text { leha } \\
\text { compL }\end{array}$ & $\begin{array}{l}\text { hügeku } \\
\text { headdress }\end{array}$ \\
\hline i-ho-lü & & & kapehe & & & \\
\hline t-HYP-PI & & & high & & & \\
\hline
\end{tabular}

\section{NON-CFS AND CFS WITH THE ANTECEDENT INTRODUCED BY THE INITIAL EPISTEMIC PARTICLE enaha AND HYP MOOD IN BOTH ANTECEDENT AND CONSEQUENT}

In this specific case, the indistinction between non-CFs and CFs is certainly due to the fact that the epistemic particle 'if' enaha, always in first position of the antecedent clause, requires, without exceptions, the HYP mood in both parts of the conditional construction.

$$
\begin{aligned}
& \text { Non-CF } \\
& \text { enaha eteholü eügünũbolü leha } \\
& \begin{array}{llll}
\text { enaha } & \text { e-te-ho-lü } & \text { e-ügü-nuN-po-lü } & \text { leha } \\
\text { EM.if } & \text { 2-gO-HYP-PNCT } & \text { 2-sick-VBLZ-HYP-PNCT } & \text { COMPL }
\end{array} \\
& \text { 'If you go, you can get sick.' }
\end{aligned}
$$

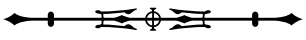


(58)

\begin{tabular}{|c|c|c|c|}
\hline $\begin{array}{l}\text { enaha } \\
\text { EM.if }\end{array}$ & $\begin{array}{l}\text { ahaki-ho-Iü } \\
\text { awake-HYP.PNCT }\end{array}$ & $\begin{array}{l}\text { kohotsi } \\
\text { evening }\end{array}$ & $\begin{array}{l}\text { inhalü } \\
\text { NEG1 }\end{array}$ \\
\hline $\begin{array}{l}\text { eha } \\
\text { COMPL }\end{array}$ & $\begin{array}{l}\text { e-te-ho-lü-i } \\
\text { 2-ir-HYP-COP }\end{array}$ & $\begin{array}{l}\text { kuigi } \\
\text { manioc }\end{array}$ & $\begin{array}{l}\text { ãdati } \\
\text { garden.ALL }\end{array}$ \\
\hline
\end{tabular}

\section{CF \\ enaha itüholü iheke inkgugipolü leha iheke \\ enaha itü-ho-lü i-heke inkgugi-po-lü leha i-heke \\ EM.if answer-HYP-PNCT 3-ERG deceive-HYP-PNCT COMPL 3-ERG}

'If he had answered, he would have deceived him.'

\section{CONCLUDING REMARKS}

The results of this preliminary descriptive study, show, in synthesis, the morphosyntactic resources available to the Kuikuro speakers to realize utterances in the conceptual and pragmatic domain of possibility, whether asserted or assumed (factual), or denied (counterfactual).

From this first organization of the analyzed data, interesting descriptive generalizations can contribute to future crosslinguistic comparisons and theoretical investigations. Looking at the Kuikuro conditional constructions, especially CFs, different patterns of the asymmetric relationship between antecedent and consequent emerge. The antecedent's dependent character is evident in a continuum between, on the one hand, dependent temporal clauses encoded as a type of time framing and containing nominalized (deverbalized) forms, and, on the other hand, a clearly biclausal pattern, the index of its dependence is expressed by epistemics and adverbs of temporal framing.

We saw that the Kuikuro verb is only inflected for mood and aspect, not for tense, and that tense morphemes are elements outside the verbal word. In order to contribute minimally to the discussion on tense in counterfactual conditional constructions, I asked a question in the introduction of this article: is Kuikuro a language of the past/non-past type, or of the future/non-future type or even of past/present/future type? Or it does not fit the existing typologies? Kuikuro (T)AM verbal inflection shows three main grammatical aspects: Punctual is interpreted as a generic past eventuality; Durative can be used in present and past contexts; the meaning of Perfect is that of an eventuality prior to the Topic Time. The only morpheme present in verbal inflection that seems to have a temporal value is the Future -ingo, which always follows the Punctual aspect and which conveys deontic values. Would this be enough to define Kuikuro as a future/ non-future language? No convincing answer can be provided at the moment.

On the other hand, looking to the verbal inflection, the Hypothetical mood - always followed by the Punctual aspect - shows a mandatory presence in CFs. I conclude that Kuikuro has a dedicated verbal morpheme for counterfactuality.

This takes us to a second question, considering the concluding statements by latridou (2000) regarding CFs and already mentioned in the introduction: CFs must contain past tense morphology in both the antecedent and the consequent, then past tense morphology is a component of CF morphology. I preliminarily adopt the following generalizations from the Kuikuro facts:

(i) Morphemes with past tense value, ouside the verbal word, convey a real past tense meaning (Top $T<U$ ttT);

(ii) The meaning of temporal past is derived from $\sigma$ (meaning of the morpheme itself) in combination with aspectual verbal morphology and other interpretive elements of $E$ (environment) (Iatridou, 2000, p. 245); 
(iii) The Hypothetical (HYP) mood seems to separate the Topic Time (TopT) from the Utterance Time (UttT), setting topic worlds (=topic time) that exclude the world of the speaker and then leading to a Past Tense interpretation (latridou, 2000, p. 246).

I am only launching, at the moment, some hypotheses that should be revisited, either to confirm them or to falsify them. Certain Kuikuro facts remain to be analyzed in future research.

\section{AKNOWLEDGMENTS}

My first debt is to the Kuikuro for the long-lasting partnership in discovering the treasures of their language. For this work, the help of Agaua and Amunegi was primordial. My research has been supported by the following Brazilian institutions: Conselho Nacional de Desenvolvimento Científico e Tecnológico (CNPq); Museu Nacional (Universidade Federal do Rio de Janeiro); Fundação Nacional do Índio (FUNAI); Fundação Carlos Chagas de Amparo à Pesquisa (FAPERJ). The DoBeS Program financed the Project for the Documentation of the Upper Xingu Carib Language or Kuikuro from 2001 to 2005. A special thanks goes to the reviewer who induced me, positively, to rewrite my text in order to satisfy very welcome requirements. I am responsible for any persistent mistake or misunderstanding.

\section{ABBREVIATIONS}

$\begin{array}{llll}1 & 1^{\text {st }} \text { person } & \text { DDIST } & \text { distal deictic } \\ 2 & 2^{\text {nd }} \text { person } & \text { DPROX } & \text { proximate deictic } \\ 3 & 3^{\text {rd }} \text { person } & \text { DTR } & \text { detransitivizer } \\ 1.2 & 1^{\text {st }} \text { person dual inclusive } & \text { DUR } & \text { durative } \\ \text { 1.2.ERG } & 1^{\text {st }} \text { person dual inclusive ergative } & \text { EM } & \text { epistemic } \\ 1.3 & 1^{\text {st }} \text { person plural exclusive } & \text { EM.if } & \text { hypothetical epistemic } \\ 1 . D & \text { EMPH } & \text { emphatic } \\ 3 . \text { PROX } & 1^{\text {st }} \text { person deictic } & \text { ERG } & \text { ergative } \text { heke } \\ \text { 3.DIST } & 3^{\text {rd }} \text { person proximal } & \text { EV.PST } & \text { evidential, distant past } \\ \text { ABL } & \text { ablative } & \text { FR } & \text { frustrative } \\ \text { ALL } & \text { allative } & \text { FUT } & \text { future } \\ \text { ANA } & \text { anaphoric } & \text { HAB } & \text { habitual } \\ \text { ANMLZ } & \text { agent nominalizer } & \text { HYP } & \text { hypothetical (mood) } \\ \text { AQU.INE } & \text { inessive into a liquid substance } & \text { INE1 } & \text { inessive } \\ \text { COM } & \text { comitative } & \text { INE2 } & \text { inessive (inside a container) } \\ \text { COMPL } & \text { completive (aspectual particle) } & \text { INTS } & \text { intensifier } \\ \text { COP } & \text { copula } & \text { INT } & \text { interrogative } \\ \text { CNTR } & \text { contrastive } & \text { ITJ } & \text { interjection } \\ \text { CR1 } & \text { epistemic of strong certainty }(\text { tiha) } & \text { LOG } & \text { logophoric } \\ \text { CR2 } & \text { epistemic of weak certainty }(\text { tsüha) } & \text { NANMLZ } & \text { non-agent nominalizer } \\ \text { DAT1 } & \text { benefactive } & \text { NMLZ } & \text { nominalizer } \\ \text { DAT2 } & \text { positive goal } & \text { NEG1 } & \text { negation (inhalü) } \\ \text { D.DIR } & \text { directional deictic } & \text { NTM } & \text { nominal tense marker }\end{array}$




$\begin{array}{llll}\text { O } & \text { object } & \text { REFL } & \text { reflexive } \\ \text { PL } & \text { plural } & \text { SIM1 } & \text { alike (hungu) } \\ \text { PNCT } & \text { punctual (aspect) } & \text { SIMLT } & \text { simultaneous } \\ \text { POSS } & \text { possessive } & \text { TEMP1 } & \text { temporal -tote } \\ \text { PRF } & \text { perfect } & \text { TEMP2 } & \text { temporal atai } \\ \text { PRSP } & \text { perspective heke } & \text { TEMP3 } & \text { temporal hata } \\ \text { PRIV } & \text { privative } & \text { TOP } & \text { topic } \\ \text { PTCP } & \text { participle } & \text { VBLZ } & \text { verbalizer }\end{array}$

\section{REFERENCES}

Basso, E. B. (2012). A Grammar of Kalapalo, a southern Cariban language. The Archive of Indigenous Languages of Latin America. https:// ailla.utexas.org/islandora/object/ailla\%3A134166

Ferreira, L. F., \& Müller, A. (2019). The relevance of future vs. non-future languages for the understanding of the role of tense in counterfactuals sentences. Revista de Estudos da Linguagem, 27(2), 1051-1099. http://dx.doi.org/10.17851/2237-2083.27.2.1051-1099

Franchetto, B. (1986). Falar Kuikúro: estudo etnolinguístico de um grupo caríbe do Alto Xingu [PhD Thesis, Museu Nacional, Universidade Federal do Rio de Janeiro, Rio de Janeiro].

Franchetto, B. (1995). Processos fonológicos em Kuikúro: uma visão auto-segmental. In L. Wetzels (Org.), Estudos fonológicos das línguas indígenas brasileiras (pp. 53-84). Editora UFRJ.

Franchetto, B. (2006). Are Kuikuro Roots Lexical Categories? In X. Lois \& V. Vapnarski (Eds.), Lexical categories and root classes in Amerindian languages (pp. 33-68). Peter Lang.

Franchetto, B. (2007). Les marques de la parole vraie en Kuikuro, langue caribe du Haut-Xingu (Brésil). In Z. Guentcheva \& J. Landaburu (Eds.), L'Enonciation médiatisée II. Le traitement épistémologique de l'information: Illustrations amerindiennes et caucasiennes (pp. 173-204). Éditions Peeters.

Franchetto, B. (2010). The ergativity effect in Kuikuro (Southern Carib, Brazil). In S. Gildea \& F. Queixalós (Eds.), Ergativity in Amazonia (pp. 121-158). John Benjamins Publishing Company.

Franchetto, B. (2015). Construções de foco e arredores em Kuikuro. ReVEL, 13(10), 246-264. http://www.revel.inf.br/files/0328c3b96d1 290a45852e709631e44d5.pdf

Franchetto, B., \& Santos, G. M. F. (2010). Cartography of expanded CP in Kuikuro (Southern Carib, Brazil). In J. A. Camacho, R. Gutiérrez-Bravo \& L. Sánchez (Eds.), Information structure in indigenous languages of the Americas: Syntactic approaches (pp. 87-113). De Gruyter Mouton.

Franchetto, B., \& Santos, G. M. F. (2014). Nominalização dos argumentos interno e externo em Kuikuro. In L. Storto, B. Franchetto \& S. Lima (Orgs.), Sintaxe e semântica do verbo em línguas indígenas do Brasil (pp. 43-64). Mercado de Letras.

Franchetto, B., \& Santos, G. M. F. (2017). The ontology of roots and the emergence of nouns and verbs in Kuikuro: Adult speech and children's acquisition. In V. Vapnarsky \& E. Veneziano (Eds.), Lexical polycategoriality: cross-linguistic, cross-theoretical and language acquisition approaches (pp. 275-306). John Benjamins Publishing Company.

Franchetto, B., \& Santos, G. M. F. (2018). Kuikuro: Ontologia e gênese de nomes e verbos. In A. B. Medeiros \& A. I. Nevins (Orgs.), O apelo das árvores: Estudos em homenagem a Miriam Lemle (pp. 377-415). Pontes Editores.

Franchetto, B., \& Thomas, G. (2016). The nominal temporal marker -pe in Kuikuro. In T. Bui \& I. Rudmila-Rodica (Eds.), SULA 9: Proceedings of the Ninth Conference on the Semantics of Under-Represented Languages in the Americas (pp. 25-40). GLSA.

Haegeman, L. (2004). Topicalization, CLLD and the Left Periphery. In B. Shaer, F. Werner \& C. Maienborn (Eds.), Proceedings of the Dislocated Elements Workshop, ZAS Berlin, November 2003 (pp. 157-192). ZASPIL 35.

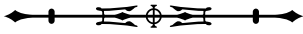


Iatridou, S. (2000). The grammatical ingredients of counterfactuality. Linguistic Inquiry, 31(2), 231-270. https://doi.org/10.1162/002438900554352

Klein, W. (1994). Time in language. Routledge.

Maia, M., Franchetto, B., Lemle, M., \& Vieira, M. D. (2019). Línguas indígenas e gramática universal. Editora Contexto.

Matthewson, L. (2004). On the methodology of semantic fieldwork. International Journal of American Linguistics, 70(4), 369-415. https:// doi.org/10.1086/429207

Meira, S., \& Franchetto, B. (2005). The southern Cariban languages and the Cariban Family. International Journal of American Linguistics, 71(2), 127-190. https://doi.org/10.1086/491633

Sanchez-Mendes, L. (2014). Trabalho de campo para análise em semântica formal. Revista Letras, 90, 277-293. http://dx.doi.org/10.5380/ rel.v90i2.36278

Santos, G. M. F. (2007). Morfologia Kuikuro: Gerando nomes e verbos [Tese de doutorado, Universidade Federal do Rio de Janeiro].

Santos, G. M. F. (2008). As classes morfológicas flexionais da língua Kuikuro. LIAMES, 8(1), 105-120. https://doi.org/10.20396/iames.v8i1.1474

Silva, G. R., \& Franchetto, B. (2011). Prosodic distinctions between the varieties of the Upper Xingu Carib language: Results of an acoustic analysis. Amerindia, (35), 41-52.

Steinen, K. (1894). Unter den naturvolkern Zentral-Brasiliens. Dietrich Reimer.

Von Fintel, K. (2001). Counterfactuals in a dynamic context. In M. Kenstowicz (Ed.), Ken Hale: A life in Language (Current Sudies in Linguistics Series, No. 36, pp. 123-152). The MIT Press. 